medRxiv preprint doi: https://doi.org/10.1101/2020.06.05.20113738; this version posted June 5, 2020. The copyright holder for this preprint

(which was not certified by peer review) is the author/funder, who has granted medRxiv a license to display the preprint in perpetuity.

All rights reserved. No reuse allowed without permission.

\title{
1 Tocilizumab is associated with reduced risk of ICU admission and mortality in
}

\section{2 patients with SARS-CoV-2 infection}

3 Estela Moreno-García, M.D.* ${ }^{1}$; Verónica Rico, M.D.*ํㅜ ${ }^{1}$ Laia Albiach, M.D. ${ }^{1}$; Daiana

4 Agüero, M.D. ${ }^{1}$; Juan Ambrosioni, M.D., Ph.D. ${ }^{1}$; Marta Bodro, M.D., Ph.D. ${ }^{1}$; Celia

5 Cardozo, M.D. ; Mariana Chumbita, M.D. ${ }^{1}$; Lorena De la Mora, M.D. ${ }^{1}$; Nicole García-

6 Pouton, M.D. ${ }^{1}$; Carolina Garcia-Vidal, M.D., Ph.D. ${ }^{1}$, Ana González-Cordón, M.D.,

7 Ph.D. ${ }^{1}$; Marta Hernández-Meneses, M.D. ${ }^{1}$; Alexy Inciarte, M.D. ${ }^{1}$; Montse Laguno,

$8 \quad$ M.D., Ph.D. ${ }^{1}$; Lorna Leal, M.D., Ph.D. ${ }^{1}$; Laura Linares, M.D. ${ }^{1}$; Irene Macaya, M.D. ${ }^{1}$;

9 Fernanda Meira, M.D. ${ }^{1}$; Josep Mensa, M.D. ${ }^{1}$; Antonio Moreno, M.D. ${ }^{1}$; Laura Morata,

10 M.D., Ph.D. ${ }^{1}$; Pedro Puerta-Alcalde, M.D., Ph.D. ${ }^{1}$; Jhon Rojas, M.D., Ph.D. ${ }^{1}$; Montse

11 Solá ${ }^{1}$; Berta Torres, M.D., Ph.D. ${ }^{1}$; Manuel Torres, M.D. ${ }^{1}$; Adrià Tomé, M.D. ${ }^{1}$; Pedro

12 Castro, M.D., Ph.D. ${ }^{2}$; Sara Fernández, M.D. ${ }^{2}$; Josep Maria Nicolás, M.D., Ph.D. ${ }^{2}$; Alex

13 Almuedo-Riera, M.D. ${ }^{3}$; Jose Muñoz, M.D., Ph.D. ${ }^{3}$; Mariana Jose Fernandez-Pittol,

14 M.D. ${ }^{4}$; Maria Angeles Marcos, M.D., Ph.D. ${ }^{4}$; Dolors Soy, M.D., Ph.D. ${ }^{5}$; José Antonio

15 Martínez, M.D., Ph.D. ${ }^{1}$; Felipe García, M.D., Ph.D. ${ }^{1}$, and Alex Soriano, M.D., Ph.D. $\dagger^{1}$.

$17 *$ both authors contributed equally to this manuscript.

$19{ }^{1}$ Department of Infectious Diseases, Hospital Clínic-Universitat de Barcelona,

IDIBAPS, Barcelona, Spain.

$21{ }^{2}$ Medical Intensive Care Unit, Hospital Clínic-Universitat de Barcelona, IDIBAPS,

22 Barcelona, Spain.

$23{ }^{3}$ Department of International Health, ISGlobal, Barcelona Centre for International

24 Health Research (CRESIB), Hospital Clínic-Universitat de Barcelona, Barcelona,

25 Spain.

NOTE: This preprint reports new research that has not been certified by peer review and should not be used to guide clinical practice. 
medRxiv preprint doi: https://doi.org/10.1101/2020.06.05.20113738; this version posted June 5, 2020. The copyright holder for this preprint

(which was not certified by peer review) is the author/funder, who has granted medRxiv a license to display the preprint in perpetuity.

All rights reserved. No reuse allowed without permission.

$26{ }^{4}$ Department of Microbiology, Hospital Clínic-Universitat de Barcelona, IDIBAPS,

27 Barcelona, Spain.

$28{ }^{5}$ Department of Pharmacology, Hospital Clínic-Universitat de Barcelona, IDIBAPS,

29 Barcelona, Spain.

30

31 Corresponding author:

32 Alex Soriano, M.D. Ph.D.

33 Department of Infectious Diseases, Hospital Clínic of Barcelona.

34 Carrer de Villarroel 170, 08036, Barcelona, Spain

35 Phone +34 932275 400; ext.2887

36 E-mail: asoriano@ clinic.cat

37

38 Funding: There are none funding or conflicts of interest to declare.

39

40 Word count: 1953 
medRxiv preprint doi: https://doi.org/10.1101/2020.06.05.20113738; this version posted June 5, 2020. The copyright holder for this preprint

(which was not certified by peer review) is the author/funder, who has granted medRxiv a license to display the preprint in perpetuity.

\section{Abstract}

42 Background

43 In some patients the immune response triggered by SARS-CoV-2 is unbalanced,

44 presenting an acute respiratory distress syndrome which in many cases requires

45 intensive care unit (ICU) admission. The limitation of ICU beds has been one of the

46 major burdens in the management worldwide; therefore, clinical strategies to avoid ICU

47 admission are needed.

49 Objective

50 We aimed to describe the influence of tocilizumab on the need of transfer to ICU or

51 death in non-critically ill patients.

Methods

A retrospective study of 171 patients with SARS-CoV-2 infection that did not qualify as requiring transfer to ICU during the first $24 \mathrm{~h}$ after admission to a conventional ward, were included. The criteria to receive tocilizumab was radiological impairment, oxygen demand or an increasing of inflammatory parameters, however, the ultimate decision was left to the attending physician judgement. The primary outcome was the need of ICU admission or death whichever came first.

61 Results

6277 patients received tocilizumab and 94 did not. The tocilizumab group had less ICU 63 admissions $(10.3 \%$ vs. $27.6 \%, P=0.005)$ and need of invasive ventilation ( 0 vs $13.8 \%$, $64 P=0.001)$. In multivariable analysis, tocilizumab remained as a protective variable (OR: 0.03, CI 95\%: $0.007-0 \cdot 1, P=0.0001)$ of ICU admission or death. 
medRxiv preprint doi: https://doi.org/10.1101/2020.06.05.20113738; this version posted June 5, 2020. The copyright holder for this preprint

(which was not certified by peer review) is the author/funder, who has granted medRxiv a license to display the preprint in perpetuity.

All rights reserved. No reuse allowed without permission.

66 Conclusion

67 Tocilizumab in the early stages of the inflammatory flare, could reduce ICU admissions

68 and mechanical ventilation use. The mortality rate of $10.3 \%$ among patients receiving

69 tocilizumab appears to be lower than other reports.

70

71 Clinical implication

72 Our results suggest that tocilizumab administered to non-critically ill patients could

73 reduce ICU admissions and mortality.

74

75 Capsule summary: Tocilizumab administered to non-critically ill patients with SARS-

$76 \mathrm{CoV}-2$ infection in the early stages of the inflammatory flare, could reduce an important

77 number of ICU admissions and mechanical ventilation use.

78

79

80 Key words: SARS-CoV-2 infection, COVID-19, tocilizumab, IL-6 inhibition, acute

81 respiratory distress syndrome (ARDS).

82

83 
medRxiv preprint doi: https://doi.org/10.1101/2020.06.05.20113738; this version posted June 5, 2020. The copyright holder for this preprint (which was not certified by peer review) is the author/funder, who has granted medRxiv a license to display the preprint in perpetuity. All rights reserved. No reuse allowed without permission.

84 Abbreviations:

85 ALS: Advanced Life Support

86 ARDS: Acute Respiratory Distress Syndrome

87 CRP: C-Reactive Protein

88 ICU: Intensive Care Unit

89 MV: mechanical ventilation

90 PCR: Polymerase Chain Reaction

91 PS: Propensity Score

92 SD: Standard Deviation

93 
medRxiv preprint doi: https://doi.org/10.1101/2020.06.05.20113738; this version posted June 5, 2020. The copyright holder for this preprint (which was not certified by peer review) is the author/funder, who has granted medRxiv a license to display the preprint in perpetuity.

\section{Introduction}

95 Infection by Coronavirus 2 (SARS-CoV-2) emerged in December 2019 in Wuhan and

96 rapidly spread around the world. SARS-CoV-2 pneumonia evolves in 2 different

97 phases, the first one is characterized by a high viral replication and classical symptoms

98 of a respiratory virus infection, including fever, malaise, myalgia, and cough (1). About

$9980 \%$ of the patients control the infection within a week but $20 \%$ of them, after the first

$1007-8$ days, develop a severe respiratory failure fulfilling the definition of acute

101 respiratory distress syndrome (ARDS) with many requiring intensive care management

102 (2). During the second week, the blood tests reveal lymphopenia, and high levels of C-

103 reactive protein (CRP), ferritin, and D-dimer values (1), all related with the activity of

104 different cytokines (IL-1beta, IL-2, IL-6, IL-8, IL-17, IFN-gamma or TNF-alpha) (3).

105 Therefore, the main therapeutic objective during the first week of treatment is to stop

106 the viral replication while in the second week blocking the tissue damage induced by

107 the cytokine storm is paramount (4).

108 In agreement with the immunopathogenesis, it has been proposed to treat patients

109 during the inflammatory flare with IL-6 inhibitors $(5,6)$. The first description included

11021 patients admitted to a Chinese hospital who received tocilizumab, a recombinant

111 humanized anti-IL-6 receptor monoclonal antibody. In a few days, symptoms improved

112 remarkably, 75\% had lowered their oxygen intake and no patient died (7). More

113 recently, Sciascia and colleagues, have reported the results of a single-arm multicentre

114 study on off-label use of tocilizumab conducted in 63 Italian patients with a severe

115 SARS-CoV-2 infection. The administration of tocilizumab within 6 first days of

116 admission was associated with an increased likelihood of survival (HR 2.2 95\% CI 1.3-

$1176.7, \mathrm{p}<0.05)(8)$. 
medRxiv preprint doi: https://doi.org/10.1101/2020.06.05.20113738; this version posted June 5, 2020. The copyright holder for this preprint (which was not certified by peer review) is the author/funder, who has granted medRxiv a license to display the preprint in perpetuity.

All rights reserved. No reuse allowed without permission.

118 On the other hand, 21 Italian patients received siltuximab, a chimeric monoclonal

119 antibody that binds to and blocks the effect of IL-6. The outcome showed that $33 \%$

120 (7/21) of patients experienced an improvement in their condition with a reduced need

121 for ventilation, 43\% (9/21) remained stable, and 24\% (5/21) worsen and required

122 intubation. However, this article is included in a repository so not yet peer reviewed (9).

123 The main objective of the present article is to describe the putative influence of

124 tocilizumab on the prognosis, defined as eventual need of transfer to the ICU or death,

125 of 171 non-critically ill patients.

127 Methods

128 From February $19^{\text {th }}$ to April $16^{\text {th }}$ patients with respiratory symptoms and radiological

129 evidence of pneumonia (uni or bilateral interstitial infiltrates) and those with respiratory

130 symptoms without pneumonia but with co-morbidity (hypertension, diabetes mellitus,

131 cancer, chronic liver diseases, chronic obstructive pulmonary disease or

132 immunosuppression) were admitted to Hospital Clínic of Barcelona in the context of

133 SARS-CoV-2 pandemic. Definitive diagnostic was stablished by a positive polymerase

134 chain reaction (PCR) from a nasopharyngeal swab during the first two weeks of

135 pandemic but once the prevalence of positive tests was $>70 \%$, the diagnosis was based

136 on clinical criteria. Clinical criteria for defining a case of SARS-CoV-2 were the

137 presence of respiratory symptoms with uni or bilateral interstitial infiltrate in the chest-

138 X ray without evidence of other potential causes (e.g. heart failure). During the study

139 period, 171 patients that did not qualify as requiring transfer to the ICU during the first

$14024 \mathrm{~h}$ after admission to a conventional hospital ward, were included.

141 For ARDS, the Berlin definition (10) was applied. When $\mathrm{PaO}_{2}$ was not available,

$142 \mathrm{SpO}_{2} / \mathrm{FiO}_{2} \leq 315$ suggested ARDS (including in non-ventilated patients) (11). 
medRxiv preprint doi: https://doi.org/10.1101/2020.06.05.20113738; this version posted June 5, 2020. The copyright holder for this preprint (which was not certified by peer review) is the author/funder, who has granted medRxiv a license to display the preprint in perpetuity. All rights reserved. No reuse allowed without permission.

143 The standard protocol included antiviral treatment that consisted of lopinavir/ritonavir

$144400 / 100 \mathrm{mg}$ BID for 7-14 days plus hydroxychloroquine $400 \mathrm{mg} / 12 \mathrm{~h}$ on the first day,

145 followed by $200 \mathrm{mg} / 12 \mathrm{~h}$ for the next 4 days. From the $18^{\text {th }}$ of March onwards,

146 azithromycin $500 \mathrm{mg}$ the first day and $250 \mathrm{mg} / 24 \mathrm{~h}$ for 4 additional days was added to

147 the regimen. In addition, a clinical trial with remdesivir was enrolling patients in our

148 institution during the study period. All patients with risk factors for thrombosis received

149 prophylactic doses of low molecular weight heparin (12). Intravenous

150 methylprednisolone was recommended for patients with disease progression to ARDS.

151 The local protocol suggested the use of tocilizumab for patients with pneumonia,

152 progressive respiratory failure (increasing fraction of inspired oxygen) and CRP $\geq 8$

$153 \mathrm{mg} / \mathrm{dL}$ or ferritin $\geq 800 \mathrm{ng} / \mathrm{mL}$ or lymphocyte count $<800$ cells $/ \mathrm{mm}^{3}$. The dose was 400

$154 \mathrm{mg} / 24 \mathrm{~h}$ iv for patients with $\leq 75 \mathrm{~kg}$ and $600 \mathrm{mg} / 24 \mathrm{~h}$ iv for those with $>75 \mathrm{~kg}$ with the

155 possibility to repeat the dose every $12 \mathrm{~h}$ up to 3 doses in case of only partial response.

156 However, due to the lack of evidence to support its efficacy, the ultimate decision about

157 using tocilizumab was left to the judgement of the attending physician.

158 Patients with severe comorbidity and a life expectancy $<6$ months were considered no

159 tributary of advanced life support (ALS). The outcome variable was a composite of the

160 need of ICU admission or death whichever came first. The last revision of medical

161 charts was April 26 $6^{\text {th }}$.

162 The Institutional Ethics Committee of the Hospital Clínic of Barcelona approved the

163 study and due to the nature of retrospective chart review, waived the need for inform

164 consent from individual patients (Comité Ètic d'Investigació Clínica; HCB/2020/0273).

\section{Statistical analysis}


medRxiv preprint doi: https://doi.org/10.1101/2020.06.05.20113738; this version posted June 5, 2020. The copyright holder for this preprint (which was not certified by peer review) is the author/funder, who has granted medRxiv a license to display the preprint in perpetuity.

All rights reserved. No reuse allowed without permission.

167 Categorical variables were described using the absolute number and percentage and

168 continuous variables using the mean and standard deviation (SD). Categorical variables

169 were compared using a Chi-squared test or Fisher exact test when necessary, and means

170 by using the Student-t test. For multivariable analysis, variables with a $P$-value $\leq 0.2$ in

171 the univariable analysis were subjected to further selection by using a backward logistic

172 regression procedure. Interactions between variables were explored. In order to reduce

173 the effect of selection bias, we estimate the propensity score (PS) to receive tocilizumab

174 as the predicted probability from a logistic regression model using tocilizumab as the

175 dependent variable. The PS was included in the multivariable analysis of the main

176 outcome. The calibration of the model was assessed by means of the Hosmer-

177 Lemeshow goodness-of-fit test. Statistical significance was defined as a two-tailed $P$

178 value $<0.05$. The analysis was performed in SPSS version 23 (SPSS Inc., Chicago, IL).

$180 \quad$ Results

181 The cohort included 171 patients, of whom 77 received tocilizumab while staying in a

182 conventional ward and 94 did not, with a mean (SD) age of $61.5(12.4)$ and $61.4(16)$

183 years, respectively. The proportion of males and the main comorbidities were similar

184 between both groups (Table 1). Patients in the tocilizumab group had more frequently

185 fever, pneumonia (interstitial infiltrate) and at day 1 they needed more often oxygen

186 therapy. C-reactive protein levels were significantly higher in the tocilizumab group

$187(9.7 \mathrm{mg} / \mathrm{dL}$ vs. $7.5 \mathrm{mg} / \mathrm{dL}, P=0.04)$ but other biological parameters were similar in both

188 groups. During patients' stay in a conventional ward, corticosteroid therapy was more

189 frequently administered in the tocilizumab group (50.6\% vs. $27.7 \%, P=0.002)$. A total

190 of 26 patients were not candidates to ALS, 10 (12.9\%) in the tocilizumab group and 16 
medRxiv preprint doi: https://doi.org/10.1101/2020.06.05.20113738; this version posted June 5, 2020. The copyright holder for this preprint (which was not certified by peer review) is the author/funder, who has granted medRxiv a license to display the preprint in perpetuity. All rights reserved. No reuse allowed without permission.

191 (17\%) among controls. The mean (SD) time from symptoms onset to hospital admission

192 in tocilizumab group was 6.5 (3.3) days while it was 5 (6.5) days in the control group.

193 The outcome of both groups, with $>90 \%$ of patients discharged alive or dead, showed

194 that patients in the tocilizumab group had significantly less ICU admissions (10.3\% vs.

$19527.6 \%, P=0.005)$ and less need of invasive ventilation ( 0 vs $13.8 \%, P=0.001)$ (Figure

196 1). The univariable analysis of our composite outcome (ICU admission or death

197 whichever came first) showed that comorbidities (hypertension, heart diseases and

198 lymphoma), the need of oxygen at day 1, a CRP > $16 \mathrm{mg} / \mathrm{dL}$ and the development of

199 cardiovascular, renal or respiratory (ARDS, invasive ventilation) complications were

200 significantly associated with the primary outcome. In contrast, tocilizumab was the only

201 one protective variable (Table 2). In the multivariable analysis, including the PS

202 estimate to receive tocilizumab as a potential confounder, tocilizumab remained as a

203 strong protective variable (OR: 0.03, CI 95\%: 0.007-0.1, $P=0.0001)$ of ICU admission

204 or death (Table 3).

205

206 Discussion

207 Monoclonal antibodies directed against key inflammatory cytokines represent a class of 208 potential adjunctive therapies for SARS-CoV-2 infected patients. The rationale for their

209 use is that the underlying pathophysiology of significant lung damage is caused by a

210 cytokine storm being IL-6 one of the main drivers. Therefore, monoclonal antibodies

211 against IL-6 or its receptor could theoretically improve clinical outcomes mainly by

212 reducing the need of ICU admission and consequently the associated mortality.

213 Tocilizumab, a monoclonal antibody IL-6 receptor antagonist, was administered to 77

214 patients admitted to a conventional ward in our hospital and the outcome was compared

215 with 94 patients also admitted in a conventional ward during the same period of time 
medRxiv preprint doi: https://doi.org/10.1101/2020.06.05.20113738; this version posted June 5, 2020. The copyright holder for this preprint (which was not certified by peer review) is the author/funder, who has granted medRxiv a license to display the preprint in perpetuity. All rights reserved. No reuse allowed without permission.

216 that did not receive tocilizumab. Although this study was not randomized, the

217 characteristics of both groups did not differ in terms of demographics and comorbidities

218 Moreover, the tocilizumab group had more severe infection (pneumonia, need of

219 oxygen at day 1 or higher CRP). Furthermore, all the patients were evaluated during the

220 same period of time so the same criteria for being transferred to the ICU was applied.

221 After adjusting for potential confounders, including the PS for receiving tocilizumab,

222 the multivariable analysis revealed that tocilizumab was an independent factor

223 associated with a reduction in the need of ICU admission and death. The need of ICU in

224 the tocilizumab group was almost 3 times lower (10.3\% vs. $27.6 \%)$ than in controls and

225 it was lower than the one reported in Wuhan hospitals $(26 \%)(1,13)$ or more recently in

226 New York (14\%) (14). The availability of ICU beds is critical for the management of

227 patients that develop a severe ARDS in few hours, therefore, reducing the need of ICU

228 beds using tocilizumab impacted directly not only on the outcome of patients that

229 received the treatment but also of those that not receiving tocilizumab or arriving too

230 late in a critically ill condition had more chances of being admitted in the ICU. In line

231 with this, the mortality of our cohort, including patients not candidates to ALS, was

$23214.2 \%$ which seems lower than that showed in previous reports, regularly $>20 \%$

$233(1,13,15)$. Indeed, the mortality rate of patients in the tocilizumab group was $10 \%$ that is

234 comparable to the one recently reported with remdesivir (15) in 53 patients (13\%).

235 Although from the beginning of the pandemic tocilizumab was recommended in the

236 general protocol, the heterogenicity of its prescription could be explained by the lack of

237 clinical randomized trials supporting its usefulness.

238 Our results suggest that tocilizumab should be administered in early phases of the

239 inflammatory flare. It is reasonable to hypothesize that other strategies directed to

240 inhibit other specific inflammatory pathways (including IL-1 with anakinra or INF- 
medRxiv preprint doi: https://doi.org/10.1101/2020.06.05.20113738; this version posted June 5, 2020. The copyright holder for this preprint (which was not certified by peer review) is the author/funder, who has granted medRxiv a license to display the preprint in perpetuity. All rights reserved. No reuse allowed without permission.

241 gamma with JAK inhibitors), or a broad-spectrum inhibition with steroids with or

242 without therapeutic strategies to reduce the pro-coagulant status, could be also effective

243 (16-18). On the other hand, although in non-severe cases after one week from symptoms

244 onset the viral viability is significantly reduced, there is data supporting the continuous

245 viral replication in severe cases (19) that could be the trigger for the inflammatory flare

246 and its maintenance. In addition, different antiviral strategies (antiviral agents, plasma

247 from convalescent patients) have demonstrated benefit in severe patients, even $>1$ week

248 after symptoms onset $(15,20-21)$. Accordingly, we consider that antiviral agents should

249 be associated with immunomodulators (22), and this explains why almost $100 \%$ of our

250 cohort received it.

251 In conclusion, while waiting for the definitive results from clinical trials with

tocilizumab (NCT04310228, ChiCTR200002976), our findings support that the

administration of tocilizumab in the early stages of the inflammatory flare, particularly

before the need of ICU admission, is more convenient and could potentially avoid an

important number of ICU admissions and mechanical ventilation use. Consequently, the mortality rate of $10.3 \%$ among patients receiving tocilizumab appears to be lower than that described by others in previously published series $(13,15,23)$. However, this is a non-randomized study and, therefore, the results should be interpreted with caution.

\section{Acknowledgements}

261 Hospital Clinic of Barcelona COVID-19 Research Group:

262 Infectious Diseases' Research Group:

263 Blanco JL, Mallolas J, Martínez E, Martínez M, Miró JM, Moreno A, and all the staff 264 members. 
medRxiv preprint doi: https://doi.org/10.1101/2020.06.05.20113738; this version posted June 5, 2020. The copyright holder for this preprint (which was not certified by peer review) is the author/funder, who has granted medRxiv a license to display the preprint in perpetuity.

266 Medical Intensive Care Unit:

267 Adrian Téllez, and all the staff members.

268

269 Department of International Health:

270 Daniel Camprubi Ferrer, Maria Teresa de Alba, Marc Fernandez, Elisabet Ferrer, Berta

271 Grau, Helena Marti, Magdalena Muelas, Maria Jesus Pinazo, Natalia Rodríguez,

272 Montserrat Roldan, Carme Subira, Isabel Vera, Nana Williams, Alex Almuedo-Riera,

273 Jose Muñoz, and all the staff members.

274

275 Department of Internal Medicine:

276 Aldea A, Camafort M, Calvo J, Capdevila A, Cardellach F, Carbonell I, Coloma E,

277 Foncillas A, Estruch R, Feliu M, Fernández-Solá J, Fuertes I, Gabara C, Grafia I,

278 Ladino A, López-Alfaro R, López-Soto A, Masanés F, Matas A, Navarro M, Marco-

279 Hernández J, Miguel L, Milisenda J, Moreno P, Naval J, Nicolás D, Oberoi H, Padrosa

280 J, Prieto-González S, Pellicé M, Ribot J, Rodríguez-Núnez O, Sacanella E, Seguí F,

281 Sierra C, Ugarte A, Ventosa H, Zamora-Martínez C, and all the staff members.

282

283 Department of Microbiology:

284 Almela M, Alvarez M, Bosch J, Casals C, Costa J, Cuesta G, Fidalgo B, Gonzàlez J,

285 Hurtado JC, Marco F, Martínez M, Mosquera M, Narvaez S, Pitart C, Rubio E, Vergara

286 A, Valls ME, Vila J, Zboromyrska Y and all the staff members.

287

288

Department of Farmacy:

289

López E, Tuset M and all the staff members.

290 
medRxiv preprint doi: https://doi.org/10.1101/2020.06.05.20113738; this version posted June 5, 2020. The copyright holder for this preprint (which was not certified by peer review) is the author/funder, who has granted medRxiv a license to display the preprint in perpetuity.

All rights reserved. No reuse allowed without permission.

291 Department of Autoimmune diseases:

292 Espigol G, Espinona $\mathrm{G}$ and all the staff members.

293 
medRxiv preprint doi: https://doi.org/10.1101/2020.06.05.20113738; this version posted June 5, 2020. The copyright holder for this preprint (which was not certified by peer review) is the author/funder, who has granted medRxiv a license to display the preprint in perpetuity.

\section{References}

1. Zhou F, Yu T, Du R, et al. Clinical Course and Risk Factors for Mortality of Adult Inpatients With COVID-19 in Wuhan, China: A Retrospective Cohort Study. Lancet 2020; 395: 1054-62. DOI: 10.1016/S0140-6736(20)30566-3.

2. Grasselli G, Zangrillo A, Zanella A, et al. Baseline Characteristics and Outcomes of 1591 Patients Infected With SARS-CoV-2 Admitted to ICUs of the Lombardy Region, Italy. JAMA 2020. April 6. (Epub ahead of print) DOI:10.1001/jama.2020.5394.

3. McGonagle D, Sharif K, O’Regan A, et Bridgewood C. The Role of Cytokines including Interleukin-6 in COVID-19 induced Pneumonia and Macrophage Activation Syndrome-Like Disease. Autoimmunity Reviews 2020. April 3. (Epub ahead of print). DOI: 10.1016/j.autrev.2020.102537.

4. Siddiqi HK, Mandeep RM. COVID-19 Illness in Native and Immunosuppressed States: A Clinical-Therapeutic Staging Proposal. J Heart and Lung Transpl 2020. DOI: 10.1016/j.healun.2020.03.012.

5. Zhang $\mathrm{C}, \mathrm{Wu} \mathrm{Z}$, Li JW, Zhao $\mathrm{H}$ and Wang GQ. The cytokine release syndrome (CRS) of severe COVID-19 and Interleukin-6 receptor (IL-6R) antagonist Tocilizumab may be the key to reduce the mortality. Int J Antimicrob Agents 2020. March 29. (Epub ahead of print). DOI: 10.1016/j.ijantimicag.2020.105954 2020. April 17. (Epub ahead of print). DOI: 10.1126/science.abb8925. 
medRxiv preprint doi: https://doi.org/10.1101/2020.06.05.20113738; this version posted June 5, 2020. The copyright holder for this preprint (which was not certified by peer review) is the author/funder, who has granted medRxiv a license to display the preprint in perpetuity. All rights reserved. No reuse allowed without permission.

8. Sciascia S, Apra F, Baffa A et al. Pilot Prospective Open, Single-Arm Multicentre Study on Off-Label Use of Tocilizumab in Patients With Severe 32359035

9. Gritti G, Raimondi F, Ripamonti D, et al. Use of siltuximab in patients with COVID-19 pneumonia requiring ventilatory support. MedRxiv 2020. DOI:10.1101/2020.04.01.20048561.

10. ARDS Definition Task Force, Ranieri VM, Rubenfeld GD, Thompson BT, Ferguson ND, Caldwell E, Fan E, Camporota L, Slutsky AS. Acute respiratory distress syndrome: the Berlin Definition. JAMA. 2012 Jun 20;307(23):2526-33. doi: 10.1001/jama.2012.5669.

11. Rice TW, Wheeler AP, Bernard GR, Hayden DL, Schoenfeld DA et Ware LB. Comparison of the $\mathrm{SpO} 2 / \mathrm{FIO} 2$ ratio and the $\mathrm{PaO} 2 / \mathrm{FIO} 2$ ratio in patients with acute lung injury or ARDS. Chest. 2007;132(2):410-417. DOI:10.1378/chest.07-0617. Thromboembolic Disease: Implications for Prevention, Antithrombotic Therapy, and Follow-up. J Am Coll Cardiol 2020. April 15. (Epub ahead of print). DOI: 10.1016/j.jacc.2020.04.031. of print). DOI:10.1001/jamainternmed.2020.0994. 
medRxiv preprint doi: https://doi.org/10.1101/2020.06.05.20113738; this version posted June 5, 2020. The copyright holder for this preprint (which was not certified by peer review) is the author/funder, who has granted medRxiv a license to display the preprint in perpetuity.

19 in the New York City Area. JAMA 2020. April 22 (Epub ahead of print). DOI: 10.1001/jama.2020.6775. Patients with Severe Covid-19. N Engl J Med 2020. April,10. (Epub ahead of print). DOI: 10.1056/NEJMoa2007016.

16. Cavalli G, De Luca G, Campochiaro C et al. Interleukin-1 blockade with highdose anakinra in patients with COVID-19, acute respiratory distress syndrome, and hyperinflammation: a retrospective cohort study. Lancet Rheumatol 2020. May 7. (Epub ahead of print) DOI: 10.1016/S2665-9913(20)30127-2

17. Ingraham NE, Lofti-Emran S, Thielen BE et al. Immunomodulation in COVID19. Lancet Respir Med 2020. May 4. DOI: 10.1016/ S2213-2600(20)30226-5.

18. Stebbing J, Phelan A, Griffin I, et al. COVID-19: combining antiviral and antiinflammatory treatments. Lancet Infect Dis. 2020;20(4):400-402. DOI: 10.1016/S1473-3099(20)30132-8.

19. Lin A, He ZB, Zhang S, Zhang JG, Zhang X, Yan WH. Early risk factors for the duration of SARS-CoV-2 viral positivity in COVID-19 patients. Clin Infect Dis 2020. April 27. (Epub ahead of print). DOI: 10.1093/cid/ciaa490. COVID-19 With Convalescent Plasma. JAMA 2020. March, 27. (Epub ahead of print). DOI: 10.1001/jama.2020.4783. and Challenges. JAMA 2020. March, 27. (Epub ahead of print). DOI:10.1001/jama.2020.4940. 
medRxiv preprint doi: https://doi.org/10.1101/2020.06.05.20113738; this version posted June 5, 2020. The copyright holder for this preprint (which was not certified by peer review) is the author/funder, who has granted medRxiv a license to display the preprint in perpetuity. All rights reserved. No reuse allowed without permission.

22. Sanders JM, Monogue ML, Jodlowski TZ, Cutrell JB. Pharmacologic Treatments for Coronavirus Disease 2019 (COVID-19): A Review. JAMA 2020. April, 13. DOI:10.1001/jama.2020.6019. Hospitalized with Severe Covid-19. N Engl J Med 2020. March, 18. (Epub ahead of print) DOI:10.1056/NEJMoa2001282.

372 
medRxiv preprint doi: https://doi.org/10.1101/2020.06.05.20113738; this version posted June 5, 2020. The copyright holder for this preprint (which was not certified by peer review) is the author/funder, who has granted medRxiv a license to display the preprint in perpetuity. All rights reserved. No reuse allowed without permission.

373 Table 1. Characteristics and outcome of patients that received or did not received 374 tocilizumab in a conventional ward.

\begin{tabular}{|c|c|c|c|}
\hline Variables & $\begin{array}{c}\text { Tocilizumab group } \\
\qquad(\mathrm{N}=77)\end{array}$ & $\begin{array}{l}\text { Control group } \\
(\mathrm{N}=94)\end{array}$ & $P$ - value \\
\hline Mean (SD) age in years & $61.5(12.4)$ & $61.4(16.0)$ & 0.957 \\
\hline Age $>62$ years old $(\%)$ & $40(52)$ & $52(55.3)$ & 0.660 \\
\hline Male $(\%)$ & $53(68.8)$ & $59(62.7)$ & 0.406 \\
\hline \multicolumn{4}{|l|}{ Comorbidities (\%) } \\
\hline Hypertension & $35(45.4)$ & $43(45.7)$ & 0.960 \\
\hline Heart diseases & $12(15.5)$ & $21(22.3)$ & 0.265 \\
\hline Chronic respiratory disease & $8(10.3)$ & $12(12.7)$ & 0.630 \\
\hline Diabetes Mellitus & $12(15.6)$ & $14(15)$ & 0.900 \\
\hline $\begin{array}{l}\text { Mean (SD) days from symptoms onset to } \\
\text { admission }\end{array}$ & $6.5(3.3)$ & $5(6.5)$ & 0.061 \\
\hline \multicolumn{4}{|l|}{ Initial characteristics (\%) } \\
\hline Fever & $86(98.7)$ & $80(85)$ & 0.002 \\
\hline Dyspnea & $33(43)$ & $47(50)$ & 0.352 \\
\hline Cough & $64(83)$ & $70(74.5)$ & 0.172 \\
\hline Normal chest $\mathrm{x}$-ray at admission & $3(4)$ & $14(15)$ & 0.017 \\
\hline Need of oxygen therapy at day 1 & $56(72.7)$ & $50(53.8)$ & 0.011 \\
\hline Positive PCR from a nasal swab & $68(88.3)$ & $82(87.2)$ & 0.831 \\
\hline \multicolumn{4}{|l|}{ Laboratory at admission mean (SD) } \\
\hline D-dimer $(\mathrm{ng} / \mathrm{mL})^{1}$ & $918.6(1354.8)$ & $1503.9(2175.4)$ & 0.100 \\
\hline Lymphocytes count (cell/mm³) & $878.9(452.8)$ & $910.1(534.6)$ & 0.686 \\
\hline C-Reactive protein $(\mathrm{mg} / \mathrm{dL})^{2}$ & $9.7(7.4)$ & $7.5(5.7)$ & 0.044 \\
\hline Serum ferritin $(\mathrm{ng} / \mathrm{dL})^{3}$ & $867.8(871)$ & $904.1(809.9)$ & 0.842 \\
\hline ARDS at any given time (\%) & $24(31.1)$ & $26(27.6)$ & 0.616 \\
\hline \multicolumn{4}{|l|}{ Treatments received $(\%)$} \\
\hline Antiviral agents ${ }^{4}$ & $77(100)$ & $91(96.8)$ & 0.164 \\
\hline
\end{tabular}


medRxiv preprint doi: https://doi.org/10.1101/2020.06.05.20113738; this version posted June 5, 2020. The copyright holder for this preprint (which was not certified by peer review) is the author/funder, who has granted medRxiv a license to display the preprint in perpetuity. All rights reserved. No reuse allowed without permission.

375

\begin{tabular}{|l|c|c|c|}
\hline \multicolumn{1}{|c|}{ Steroid prior ICU admission } & $39(50.6)$ & $26(27.7)$ & 0.002 \\
\hline Not candidate to ALS (\%) & $10(12.9)$ & $16(17)$ & 0.465 \\
\hline Mean (SD) days of follow up & $11.2(6.2)$ & $14.7(10.6)$ & 0.027 \\
\hline Outcomes (\%) & $8(10.3)$ & $26(27.6)$ & 0.005 \\
Need of ICU & $3(3.9)$ & $1(1)$ & 0.198 \\
Need of no invasive MV & - & $13(13.8)$ & 0.001 \\
Need of invasive MV & - & $9(9.6)$ & - \\
Extubation & $5(6.5)$ & $21(22.3)$ & - \\
Discharge from ICU & $65(84.4)$ & $71(75.5)$ & 0.152 \\
Hospital discharged & $4(5.2)$ & $6(6.4)$ & 0.503 \\
Still in the hospital & $8(10.3)$ & $17(18)$ & 0.156 \\
\hline Mortality (\%) & & $5(6.4)$ & 0.337 \\
Global mortality & $2(3)$ & $12(75)$ & 0.420 \\
Mortality in: & & $50)$ \\
Not candidates to ALS & & & \\
Candidates to ALS & & & \\
\hline
\end{tabular}

376 PCR, polymerase chain reaction. ADRS, adult distress respiratory syndrome. ICU, intensive care unit.

377 ALS, advanced life support. MV, mechanical ventilation.

$378{ }^{1}$ Measured in 110 patients.

$379 \quad{ }^{2}$ Measured in 168 patients.

$380 \quad{ }^{3}$ Measured in 86 patients.

$381 \quad{ }^{4}$ see material and methods for antivirals used in our protocol.

382 
medRxiv preprint doi: https://doi.org/10.1101/2020.06.05.20113738; this version posted June 5, 2020. The copyright holder for this preprint (which was not certified by peer review) is the author/funder, who has granted medRxiv a license to display the preprint in perpetuity.

All rights reserved. No reuse allowed without permission.

384 Figure 1. Differences between tocilizumab group and no-tocilizumab group in 385 terms of ICU admission, need of mechanical ventilation and mortality.

386

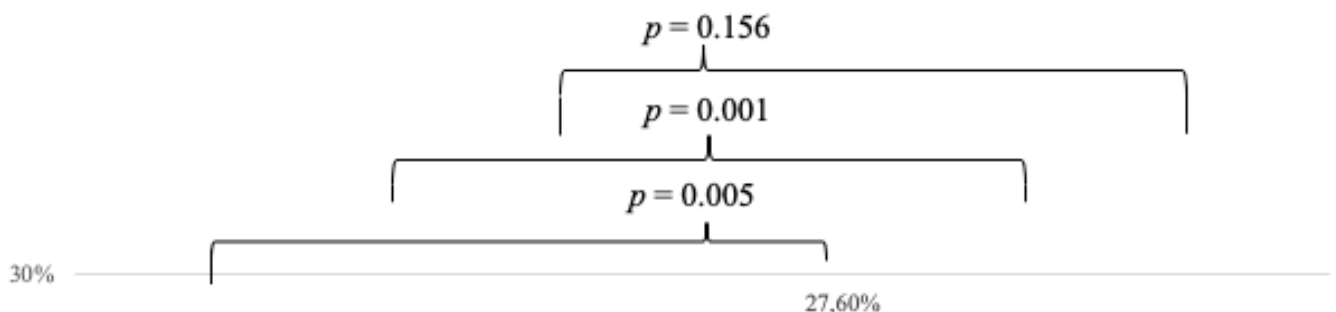

388 ICU, Unit Care Unit. MV, Mechanical Ventilation. 
medRxiv preprint doi: https://doi.org/10.1101/2020.06.05.20113738; this version posted June 5, 2020. The copyright holder for this preprint (which was not certified by peer review) is the author/funder, who has granted medRxiv a license to display the preprint in perpetuity. All rights reserved. No reuse allowed without permission.

Table 2. Variables associated with ICU admission and/or death whichever came

391 first.

\begin{tabular}{|c|c|c|c|}
\hline Variables & $\begin{array}{l}\text { No ICU admission } \\
\text { and/or death, } \mathrm{N}=121\end{array}$ & $\begin{array}{c}\text { ICU admission or } \\
\text { death, } \mathrm{N}=\mathbf{5 0}\end{array}$ & $P$ - value \\
\hline Age $>62$ years $(\%)$ & $57(47)$ & $35(70)$ & 0.006 \\
\hline Male sex $(\%)$ & $77(63.6)$ & $35(70)$ & 0.426 \\
\hline Mean (SD) follow-up, days & $12(8.347)$ & $16.6(9.858)$ & 0.006 \\
\hline Comorbidities (\%) & $98(81)$ & $48(96)$ & 0.012 \\
\hline Hypertension & $49(40.5)$ & $29(58)$ & 0.037 \\
\hline Diabetes Mellitus & $20(16.5)$ & $6(12)$ & 0.453 \\
\hline Heart diseases & $17(14)$ & $16(32)$ & 0.007 \\
\hline Chronic respiratory disease & $11(9)$ & $9(18)$ & 0.099 \\
\hline Neoplasia & $11(9)$ & $6(12)$ & 0.580 \\
\hline Dyslipemia & $8(6.6)$ & $6(12)$ & 0.356 \\
\hline Lymphoma & $2(1.7)$ & $5(10)$ & 0.012 \\
\hline Solid organ transplantation & $5(4)$ & $3(6)$ & 0.693 \\
\hline Human Immunodeficiency Virus & $1(0.8)$ & - & 1 \\
\hline $\begin{array}{l}\text { Mean (SD) days from symptoms onset to } \\
\text { admission }\end{array}$ & $5.98(6.124)$ & $4.86(3.084)$ & 0.223 \\
\hline \multicolumn{4}{|l|}{ Initial characteristics $(\%)$} \\
\hline Fever & $112(92.6)$ & $44(88)$ & 0.337 \\
\hline Dyspnoea & $59(48.8)$ & $21(42)$ & 0.420 \\
\hline Cough & $98(81)$ & $36(72)$ & 0.222 \\
\hline Normal chest $\mathrm{x}$-ray at admission & $12(10)$ & $5(10)$ & 0.987 \\
\hline Need of oxygen therapy at day 1 & $68(56.7)$ & $38(76)$ & 0.018 \\
\hline Positive PCR from nasal swab & $105(86.8)$ & $45(90)$ & 0.559 \\
\hline \multicolumn{4}{|l|}{ Laboratory at admission (\%) } \\
\hline Lymphocytes count ${ }^{1}<700$ cell $/ \mathrm{mm}^{3}$ & $36(29.8)$ & $18(36)$ & 0.424 \\
\hline
\end{tabular}


medRxiv preprint doi: https://doi.org/10.1101/2020.06.05.20113738; this version posted June 5, 2020. The copyright holder for this preprint (which was not certified by peer review) is the author/funder, who has granted medRxiv a license to display the preprint in perpetuity. All rights reserved. No reuse allowed without permission.

392

\begin{tabular}{|l|c|c|c|}
\hline \multicolumn{1}{|c|}{ C-Reactive protein ${ }^{2}>9 \mathrm{mg} / \mathrm{dL}$} & $39(32.5)$ & $20(41.7)$ & 0.261 \\
C-Reactive protein ${ }^{2}>16 \mathrm{mg} / \mathrm{dL}$ & $23(19)$ & $25(50)$ & 0.0001 \\
\hline Treatments received (\%) & $118(97.5)$ & $50(100)$ & 0.261 \\
Antiviral agents & $44(36.4)$ & $21(42)$ & 0.490 \\
Steroids prior ICU admission & $65(53.7)$ & $12(24)$ & $<0.0001$ \\
Tocilizumab & & $13(7.6)$ & 0.012 \\
\hline Complications (\%) & $5(4)$ & $30(60)$ & 0.0001 \\
Cardiovascular & $14(11.6)$ & $12(24)$ & 0.0001 \\
ARDS in the conventional ward & $3(1.8)$ & $13(26)$ & 0.0001 \\
Acute Kidney Injury & - & $18(36)$ & 0.0001 \\
\hline Invasive ventilation & $8(6.6)$ & & \\
\hline Not candidate to ALS & & & \\
\hline
\end{tabular}

393 PCR, polymerase chain reaction. ICU, intensive care unit. ADRS, adult distress respiratory syndrome.

394 ALS, advanced life support.

$395{ }^{1}$ Measured in 110 patients.

$396 \quad{ }^{2}$ Measured in 168 patients.

$397{ }^{3}$ See material and methods section for antivirals used in our protocol. 
medRxiv preprint doi: https://doi.org/10.1101/2020.06.05.20113738; this version posted June 5, 2020. The copyright holder for this preprint (which was not certified by peer review) is the author/funder, who has granted medRxiv a license to display the preprint in perpetuity.

All rights reserved. No reuse allowed without permission.

399 Table 3. Variables significantly associated with the risk of being admitted in the ICU and/or death 400 in the multivariable analysis.

401

\begin{tabular}{|l|c|r|}
\hline Variables $^{1}$ & $\begin{array}{c}\text { Adjusted odd ratio } \\
(\mathbf{9 5 \%} \mathbf{C I})\end{array}$ & \multicolumn{1}{|c|}{ - value } \\
\hline Lymphoma & $16.7(1.7-157.3)$ & 0.04404 \\
\hline Heart disease & $2.9(0.9-9.4)$ & 0.07405 \\
\hline Need of oxygen at day 1 & $3.4(1.1-10.5)$ & 0.03406 \\
\hline ARDS prior to ICU admission & $50.7(10.4-245.7)$ & 0.000407 \\
\hline Not candidate to ALS & $3.8(1.2-11.7)$ & 0.04408 \\
\hline Tocilizumab & $0.03(0.007-0.1)$ & 0.000409 \\
\hline
\end{tabular}

411 ARDS, Adult respiratory distress syndrome. ICU, intensive care unit. ALS, advanced life support.

$412{ }^{1}$ Variables included in the analysis: age $>62$ years, chronic respiratory disease, hypertension heart

413 disease, lymphoma, C-reactive protein $>16 \mathrm{mg} / \mathrm{dL}$, need of oxygen at day 1 , cardiovascular

414 complications, ARDS in the conventional ward, not candidate to ALS, tocilizumab administration,

415 propensity score to receive tocilizumab. Acute kidney injury and invasive ventilation were complications

416 that occurred after being admitted in the ICU, therefore, they were not included for the main outcome

417 analysis since this include the need of being admitted in the ICU.

418 